\title{
AÇÕES AFIRMATIVAS E 0 DEBATE SOBRE RACISMO NO BRASIL
}

Andreas Hofbauer

Assistimos hoje a um debate acirrado em torno da implantação de políticas de Ação Afirmativa. Sobretudo o projeto de cotas para negros em universidades públicas tem dividido a opinião pública. Esta discussão ganhou fôlego quando, na época dos preparativos para a Terceira Conferência Mundial contra Racismo, Discriminação Racial, Xenofobia e Outras Formas de Intolerância (Durban, 2001), e sob pressão do movimento negro, o governo sinalizava disposição de criar mecanismos de "discriminação positiva" para combater o racismo no Brasil (cf. tb. Telles, 2003: 86-97).

Se, durante muito tempo, os governos brasileiros se orgulharam de pregar na cena internacional a ausência do racismo no país, no governo F.H. Cardoso pôde-se perceber claros sinais de uma mudança de discurso e de ação: pela primeira vez, reconheceu-se oficialmente a existência de um "problema racial" e se passou a estar preocupado com estratégias específicas de combatê-lo. Hoje, há um amplo consenso entre os especialistas e na sociedade brasileira como um todo de que o país não está livre da pecha da discriminação racial $^{1}$. 
A proposta de introduzir ações afirmativas como meio para contrabalançar os efeitos históricos de discriminações estruturais, não consegue, porém, gerar consenso nem mesmo entre estudiosos do assunto. Enquanto alguns entendem a introdução de ações afirmativas como uma espécie de precondição para a superação da discriminação racial - uma vez que, segundo esta interpretação, a discriminação positiva ajudará os historicamente desprivilegiados a criar e fortalecer uma identidade positiva -, outros vêem em tais medidas um ataque perigoso contra a "maneira tradicional brasileira" de se relacionar com as diferenças humanas, e temem que por meio delas possam ser instigados conflitos raciais abertos.

Como explicar avaliações tão divergentes? Como entender tanta polêmica e emoção nos debates acadêmicos, no mundo da mídia, no movimento negro? É evidente que por trás dessas brigas há orientações divergentes de ordem ideo10 lógica e/ou teórica ligadas a diferentes ideais de sociedade, de noções de igualdade e de desigualdade. E há também divergências fundamentais a respeito da compreensão de conceitos-chave que raramente são explicitadas pelos debatedores. Quero mostrar que as diferentes acepções de categorias-chave como "raça", "negro" e "branco" devem-se, em boa parte, a tradições acadêmicas específicas e têm implicações importantes para a maneira como os debatedores enxergam o fenômeno da discriminação racial e para as estratégias que desenvolvem. Quero argumentar também que o fato de o debate sobre a introdução de cotas ter se acirrado basicamente numa confrontação entre a defesa de um "grupo específico" (os negros) versus a defesa de uma espécie de "etos específico" tem a ver exatamente com

1. Veja, tb., a pesquisa Datafolha de 1995 que revelou que $89 \%$ dos brasileiros afirmam que há "preconceito racial" no Brasil. Revelador é, contudo, também, que, segundo esta mesma pesquisa, apenas $10 \%$ dos pesquisados admite ter atitudes racistas (Turra e Venturi, 1995: 11). 
essas duas correntes que têm marcado a história da reflexão sobre a questão do negro no Brasil. E que essa confrontação acadêmico-intelectual, que se reproduz também no mundo da mídia, ocorre em detrimento de um aprofundamento da discussão sobre as raízes e o funcionamento do racismo, e, inclusive, em detrimento de uma intensificação do diálogo com recentes e ricas reflexões teóricas sobre o racismo que vêm sendo produzidas em outros lugares do mundo.

No meio das inúmeras e diferentes abordagens teóricas existentes é possível discernir dois pólos de argumentação que se opõem. De um lado, podemos verificar uma tradição basicamente sociológica, que se concentra na análise das "relações" entre "negros" e "brancos", e mais especificamente no aspecto da desigualdade social entre estes "grupos raciais". Do outro lado do espectro, temos uma série de estudos que partem de preocupações e concepções clássicas da Antropologia Social e Cultural.

\section{0 olhar sociológico}

Para podermos avaliar melhor o debate atual, quero resumir, de forma sucinta, como em cada uma dessas correntes teóricas, conceitos-chave como "negro", "raça" e o problema do racismo têm sido abordado. A tradição da Sociologia das Relações Raciais remete, em termos teóricos e metodológicos, à Escola de Chicago e teve seu início no Brasil com os estudos da UNESCO promovidos nos anos 1950 (cf. os importantes trabalhos de intelectuais, como F. Fernandes, A.L. Costa Pinto, O. Ianni, F.H. Cardoso). Nesta linha de pesquisa, há uma propensão a vincular a delimitação de "grupos raciais" diretamente à análise de assimetrias socioeconômicas. R. Park (sobretudo 1950) já buscava detectar contextos específicos em que surgem "relações raciais" e, mais tarde, em 1970, J. Rex argumentaria que são as condições estruturais - conflitos em torno de recursos escassos, situações de exploração extrema etc. - que fazem com 
que relações sociais sejam definidas em termos de "relações raciais". Mas, pode ocorrer também, e não apenas nos "estudos raciais" clássicos (como, por exemplo, nos trabalhos de Park), que categorias-chave como "raça", "negro"," branco", etc. sejam usadas num mesmo texto de forma indiscriminada, às vezes como instrumentos analíticos (que transcrevem a força da engenharia socioeconômica), e outras vezes, como reprodução dos termos locais (êmicos) (cf. também a crítica de Carter, 2000: 12).

Com o decorrer do tempo, tendências marxistas vão ganhar espaço dentro da perspectiva sociológica do estudo das "relações raciais". Assim, O. Cox descreve, no seu livro Caste, class and race (1948), o surgimento de "relações raciais" como um co-produto da exploração capitalista. Para ele, trata-se de relações que são determinadas pelos fatores trabalho, capital e lucro (Cox, 1970 [1948]: 333, 393; cf. tb. as análises de Solomos \& Back, 1996: 3-7; e 37-42).

12 No Brasil, pesquisadores como Cardoso e Ianni seguiam uma argumentação economicista semelhante para explicar como, segundo eles, teriam se firmado, na época da escravidão, dois "grupos sociais/raciais" antagônicos (brancos e não-brancos). "Nesse contexto", escreve Ianni, "o negro e o mulato são acepções da mesma categoria do sistema econômico; fornecem a mão-de-obra produtora de valores" (Ianni, 1988: 112). Ou ainda mais adiante: “[...] o negro e o mulato livre" são tratados como "membros de 'outro' grupo, indivíduos ligados racial e socialmente aos escravos de que procedem" (: 152). Percebe-se aqui claramente que a definição da cor/raça dos agentes sociais subordina-se à análise da função que os sujeitos exercem dentro do sistema econômico.

No âmbito de pesquisadores ligados aos Estudos das Relações Raciais, surgiram duas importantes teses que buscam dar uma resposta teórica para o fenômeno do racismo. F. Fernandes entendia a desigualdade racial persistente na sociedade brasileira, em primeiro lugar, como um "resíduo 
do antigo regime" (Fernandes, 1978, I: 268). Para ele também, a sociedade escravista representava um mundo dicotomizado entre brancos e negros, "dois mundos cultural e socialmente separados, antagônicos e irredutíveis um ao outro" (Fernandes, in: Bastide e Fernandes, 1971: 91). "Na verdade", diz o autor, "senhores e escravos formavam duas 'sociedades' distintas, que coexistiam no seio de uma ordem social inclusiva" (: 95).

Já no projeto que F. Fernandes e R. Bastide elaboraram para a pesquisa coordenada pela UNESCO, os dois cientistas faziam menção a um problema de ordem teórico-conceitual que este estudo envolvia. Constatavam que a "natureza e função" do "preconceito racial" ainda não tinham sido bem conhecidas pela sociologia e frisavam ainda o fato de que, até então, a maioria dos estudos empíricos deste tipo havia sido feita nos Estados Unidos, ou seja, em situações de “segregação social” (Bastide e Fernandes, 1951: 3). Não obstante certas dúvidas, e declarando-se conscientes do perigo da "substancialização do conceito, tão freqüente nos trabalhos sobre o fenômeno" (: 47), assumiam como orientação teórica a definição dada por Park e explicavam: "Nesse sentido, parece que o preconceito racial tende a desenvolverse como conseqüência natural do contacto intermitente ou contínuo de pessoas ou grupos de pessoas pertencentes a 'raças' diversas, sempre que condições de desigualdade econômica e social contrastam marcas raciais com discrepâncias notórias quanto às ocupações, às riquezas, ao nível de vida, à posição social e à educação" (: 7; grifo meu).

Pressupondo, implicitamente, que existem grupos (étnicos, raciais) bem consolidados que se reconhecem como tais, a manifestação do preconceito é apresentada, nesta linha de argumentação, como um dado que se deve diretamente à mecânica socioeconômica. A subordinação do mundo das idéias à análise da infra-estrutura (mais exatamente, à análise da função social que os grupos ocupam 
nos processos socioeconômicos) faz com que não se invista num estudo de ideários que poderiam ter alguma influência sobre a valorização e a depreciação de tipos humanos e, desta forma, também sobre a delimitação de fronteiras grupais.

Mesmo que Fernandes e Bastide enfatizem (seguindo o raciocínio de Myrdal) que o conceito de raça deve ser usado no sentido sociológico ("um conceito social e convencional"), admitindo também que no Brasil seu significado social ainda não foi determinado e até reconhecendo que, não raramente, pessoas com traços negróides salientes passam "por brancas" e são tratadas como tais (Bastide e Fernandes, 1951: 46), os autores partirão, nas suas reflexões, da existência de dois "grupos raciais", sem tematizar a formação de suas fronteiras. De todo modo, pode-se constatar na obra de Fernandes uma nítida tendência de incluir os "mulatos" na categoria de "negros" - "homens de cor" (p.ex., Fernandes, 1971: 87, 91, 109, e 1978, I: 13).

14 Em vários momentos de sua análise das relações entre negros e brancos na sociedade de classes de sua época, Fernandes faz comentários sobre a força do preconceito, mas não aprofunda a reflexão teórica a respeito do fenômeno em si, provavelmente porque o relaciona diretamente com um modo de produção específico que ele julgava arcaico e em fase de decadência. Num texto publicado em 1969 ("The Weight of the Past"), afirma enfaticamente que "[...] as manifestações de preconceito e discriminação raciais nada têm a ver com a competição ou rivalidade entre negros e brancos nem com o agravamento real ou possível de tensões raciais. Elas são a expressão de mecanismos que de fato perpetuam o passado no presente. Elas representam a continuação da desigualdade racial tal como se dava no antigo sistema de castas" (apud Hasenbalg, 1979, p. 74). Ou seja, Fernandes tende a atribuir as dificuldades dos exescravos e a permanência das discriminações na moderna sociedade de classes a "atrasos" e "desajustes" resultantes do 
"antigo sistema" socioeconômico, ou seja, ao fenômeno que ele chama também de "demora cultural" (Fernandes, 1987, II: 460$)^{2}$. E a esperança de Fernandes era a de que a "nova ordem social igualitária”, tornada possível pela Abolição e pela República, deveria superar tais descompassos (in: Bastide e Fernandes, 1971: 12).

No final da década de 1970, quando o país estava caminhando para a abertura e redemocratização, o tema da discriminação e a tradição dos estudos raciais foi retomada por alguns pesquisadores como C. Hasenbalg. Este sociólogo já não vê a presença do preconceito na sociedade urbana moderna como uma mera herança do antigo regime. Para ele, a sociedade de classes conferiu uma nova função ao preconceito e à discriminação raciais (Hasenbalg, 1979: 77).

Hasenbalg resume sua tese em dois pontos: “a) a discriminação e preconceitos raciais não são mantidos intactos após a abolição mas, pelo contrário, adquirem novos significados e funções dentro das novas estruturas; e b) as práticas racistas do grupo dominante branco que perpetuam a subordinação dos negros não são meros arcaísmos do passado, mas estão funcionalmente relacionados aos benefícios materiais e simbólicos que o grupo branco obtém da desqualificação competitiva dos não brancos" (: 85).

Ele critica a "perspectiva marxista ortodoxa" (p.ex. Cox), que explica a situação dos negros quase exclusivamente pela sua posição econômica como trabalhador e segundo a qual racismo e preconceito não passam de epifenômenos das relações econômicas (: 109). Afirma que "o racismo é mais do que um reflexo epifenomênico da estrutura econômica ou um instrumento conspiratório usado pelas classes dominantes para dividir os trabalhadores" (: 118).

2. Escreve Fernandes: "[Os negros] não estavam nem estrutural nem funcionalmente ajustados às condições dinâmicas de integração e de expansão da ordem social competitiva" (Fernandes, 1978, I: 56) 
A partir da década de 1980, pesquisadores ligados aos ou inspirados nos Estudos das Relações Raciais têm conseguido - com uma grande quantidade de trabalhos empíricos e com dados estatísticos detalhados - comprovar a existência da discriminação do grupo dos "negros" em relação aos "brancos" em todos os âmbitos da vida social. As reflexões teóricas dos Estudos das Relações Raciais, que, em termos metodológicos, partem da premissa de que existem "grupos raciais ou de cor" com limites fixos, têm se adaptado bem ao uso de métodos quantitativos e ao uso das categorias do censo oficial brasileiro ${ }^{3}$. Já nos seus primeiros trabalhos, Hasenbalg, pioneiro em estudos empíricos sobre discriminação e desigualdades raciais baseados em dados estatísticos, fundia as categorias "pardo" e "negro", usadas nos censos oficiais, para criar uma dicotomização analítica entre "brancos" e "não-brancos".

Uma contribuição muito importante para a constru16 ção de um discurso crítico, que alerta para as conseqüências do fenômeno do racismo, tem vindo dos vários grupos do movimento negro, com o qual pesquisadores associados aos Estudos das Relações Raciais têm mantido contatos intensos desde a época de Fernandes. Sobretudo a partir do fim da década de $1970^{4}$, a "nova" militância negra, tem sublinhado (diferentemente dos movimentos dos anos 1920

3. O IBGE tem trabalhado com a perspectiva de autodenominação, sendo que a pessoa tem de optar entre quatro categorias dadas: preto, pardo, branco, amarelo e, mais recentemente, também indígena. Pesquisadores como Hasenbalg, Valle Silva e, posteriormente, muitos outros, sobretudo adeptos e simpatizantes da militância negra, costumam somar os dados dos grupos "pretos" e "pardos" (das estatísticas oficiais) para falar da situação social dos "negros" - ou seja, postula-se que as categorias "pretos" e "pardos" do censo representam o grupo dos "negros".

4. Um marco na reorganização das forças políticas negras foi certamente a fundação do Movimento Negro Unificado em 1978, que, aliás, teve também o apoio de intelectuais importantes. O Movimento Negro Unificado surgiu com duas propostas fundamentais: combater a discriminação racial e denunciar a "democracia racial" como uma ideologia opressora (cf. o nome originário deste grupo: Movimento Negro Unificado Contra a Discriminação Racial — MNUCDR). 
e 1930, por exemplo ${ }^{5}$ ) a importância de delimitar o grupo, que pretende representar, em relação a outros componentes nacionais.

O papel de pesquisadores e militantes negros dos EUA, como também aquele de fundações norte-americanas (cada vez mais atuantes nesta questão), para o fortalecimento de uma "idéia essencializada" da diferença (para o fortalecimento de um "discurso racialista") ainda não foi pesquisada, provavelmente também por constituir um tema politicamente bastante delicado ${ }^{6}$. De qualquer forma, não se pode negar que desde a época dos estudos da UNESCO (anos 1950), existem trocas e influências entre pesquisadores e militantes dos dois países ${ }^{7}$. E é perceptível também que nas bibliografias de trabalhos recentes, efetuados por importantes intelectuais brasileiros que se entendem como negros, há uma nítida preferência por trabalhos de pesquisadores norte-americanos, em detrimento de estudos feitos em outros países onde também ocorrem atualmente discussões teóricas importantes sobre

5. Assim, p.ex., a Frente Negra Brasileira homenageava, no dia 13 de Maio, além da Princesa Isabel, os abolicionistas mais conhecidos, sem distinção de sua cor de pele (organizavam-se "romarias cívicas" para os seus túmulos); houve, inclusive, cooperação ativa de "brancos" nas atividades na sede deste movimento (cf. Pinto, 1993: 100), algo impensável no Movimento Negro Unificado, que se articularia na época da reabertura do país (cf., ainda, a colaboração ativa de vários intelectuais e artistas brancos nas atividades do Teatro Experimental do Negro, na década de 1940).

6. Veja, p.ex., a polêmica que a publicação do texto de Bourdieu e Wacquant ("Sur les ruses de la raison impérialiste", 1998) gerou. Um caderno inteiro dos Estudos Afro-Asiáticos $\left(\mathrm{n} .{ }^{\circ} 1,2002\right)$ foi dedicado a reflexões críticas sobre o ensaio dos dois intelectuais franceses.

7. Cf., p.ex., a participação de um grupo de pesquisadores liderado por Wagley no projeto da UNESCO (nos anos 1950) e a estadia de O. Nogueira nos EUA neste mesmo período. Há uma longa tradição de pesquisa norte-americana que se dedica ao estudo da questão racial no Brasil (p.ex., Skidmore, Degler, Hanchard, Marx, Andrews, Telles, Butler). Hoje, podemos constatar que cada vez mais intelectuais negros brasileiros têm contatos pessoais com organismos de pesquisa norte-americanos. Há instituições que financiam, diretamente, pesquisas sobre a questão racial no Brasil e/ou bancam, especificamente, bolsas de estudos para negros brasileiros estudarem nos EUA. 
o fenômeno do racismo e temas como multiculturalismo e ações afirmativas.

Na história do debate brasileiro sobre a "questão racial", marcada pelo ideário do branqueamento e pelo mito da "democracia racial" (cf. tb. Hofbauer, 2003), a introdução de concepções essencializadas ("tipológicas") das diferenças humanas serviu como um mecanismo para questionar o discurso hegemônico. Quero argumentar, porém, que, se, de um lado, a essencialização de categorias como "negro" e "branco" (presente tanto no discurso dos movimentos negros como nos Estudos das Relações Raciais) tornou possível "desmascarar os mitos", esta mesma postura teóricoconceitual não oferece pistas teórico-metodológicas para interpretar a complexa questão das identidades (e dos ideários) e, desta forma, tende a simplificar e distorcer o fenômeno do racismo em si.

Uma contribuição importante, sobretudo em termos de 18 fundamentação teórica, para as reivindicações pela implementação de políticas de ação afirmativa em universidades públicas tem sido dada pelos inúmeros trabalhos valiosos de A.S. Guimarães. Esse autor entende que o uso da categoria "cor" em análises acadêmicas tem dificultado a compreensão da discriminação racial do Brasil (cf. Guimarães, 1999: 44). Segundo este raciocínio, a grande quantidade de termos de cor que são usados no cotidiano (moreno claro, moreno escuro, moreninho, marrom etc.) não passa de uma espécie de "representação metafórica”, de uma "imagem figurada” do velho conceito clássico de raça (Guimarães, 2002: 43).

Guimarães propõe a adoção de um "discurso racialista” não apenas como um recurso de autodefesa que deve ajudar a recuperar o sentimento étnico, o sentimento de dignidade, de auto-estima e de autoconfiança da população afro-descendente (1995: 43). Ele entende e aplica a racialização como um instrumento simultaneamente acadêmi- 
co e político: para este autor, "raça" serve como uma "base conceitual-acadêmica" que permite articular e agilizar a luta por políticas públicas compensatórias ${ }^{8}$.

Chama a atenção também o fato de que Guimarães ataca, de um lado, o uso de uma noção essencialista de cultura na análise de alguns autores que, ao comparar a história dos EUA com aquela do Brasil, distinguem "diferentes vias de modernidade negra” (Guimarães, 2003: 57, e 2005) e, ao mesmo tempo, promove a essencialização no plano das fronteiras grupais. A afirmação de que "toda formação étnica” requer "uma definição forçosamente essencialista” (Guimarães, 1995: 44; 1999: 59) reflete uma "visão de dentro", daqueles que estão empenhados na afirmação e na defesa de determinadas "fronteiras étnicas" (ou ainda uma perspectiva explicitamente normativa); ao mesmo tempo, ignora a vasta bibliografia antropológica a respeito da "etnicidade" que tem destacado, desde o final dos anos 1960, o seu caráter relacional, situacional e processual e, com isso, tem alertado para a insuficiência e a invalidade do uso de noções essencialistas, para fins analíticos, no âmbito dos estudos de "grupos étnicos".

Seguindo um amplo consenso entre os especialistas no assunto, Guimarães declara também que "raça” não deve ser entendida como uma categoria biológica, mas "tem existência nominal, efetiva e eficaz apenas no mundo social" (2002: 50). Mas, como para tantos outros pesquisadores que seguem as premissas dos Estudos das Relações Raciais, também para Guimarães, a delimitação de grupos ("raças") não é objeto de uma reflexão teórica à parte.

8. Guimarães admite que a autoclassificação de cor da população nem sempre corresponde à classificação usada pelo IBGE e por diversos autores em textos sociológicos. A defesa do uso da categoria "raça" (de uma noção essencializada de negro) ganha, aqui, visivelmente, um teor pragmático: justificar-se-ia pelo objetivo político. Escreve Guimarães: "Na ausência de tal identidade [social/racial], o legislador poderá estar ajudando a criar, com sua legislação, a comunidade sobre a qual pretende legislar" (Guimarães, 1997: 240). 
Há uma tendência de tratar categorias como "negro", "branco" e "raça" como fatores diretamente ligados à (manutenção da) estrutura sócioeconômica, e/ou como "dados naturais" que supostamente prescindem de qualquer explicação. Esta ambigüidade conceitual deve-se, provavelmente, em parte a uma tradição funcional-estruturalista de abordar o conceito "raça/cor", e em parte a noções naturalizadas das diferenças humanas que, segundo P. Wade, permeiam ainda os Estudos das Relações Raciais. Wade mostra que, embora a grande maioria dos pesquisadores (p. ex., J. Rex e M. Banton) afirme que raça é uma construção social, ocorre, freqüentemente, que as "variedades fenotípicas" são tratadas como um dado biológico neutro. Desta forma, argumenta Wade, transfere-se a "conceituação naturalizada" da idéia de raça para o "fenótipo"

Mesmo que, mais recentemente, alguns autores tenham começado a se incomodar com o fato de serem acusados 20 de promover a racialização das diferenças e mesmo que, retoricamente, tenham procurado destacar que não há nada de "natural" em categorias como "raça" e "negro", nas suas abordagens "raça" e "negro" continuam sendo tratados como "categorias pré-discursivas" às quais é atribuída, implicitamente, uma "existência própria" que independe e transcende diferentes épocas, contextos culturais e interpretações grupais e individuais distintas.

Esta atitude em relação à definição dos "grupos raciais" ("grupos de cor"), que marca toda a tradição dos Estudos

9. Wade, e também D. Haraway, insistem em dizer que "o reino da natureza" não se apresenta aos seres humanos como um campo neutro. Os dois pesquisadores partem do princípio de que o "conhecimento é um processo social, de maneira que o conhecimento sobre a natureza não pode ser simplesmente separado das categorias culturais daqueles que produzem o conhecimento" (Wade, 1993: 31). Portanto, diz Wade, "a natureza é também uma construção social"; e Haraway complementa: "biology remain [s] a human culture-specific discourse, not the body of nature itself" (in: Wade, 1993: 18, 31). 
de Relações Raciais, não deixa de ter seu reflexo sobre a maneira como está sendo conduzido o debate atual sobre a implementação de "cotas para negros" em universidades públicas. Recentemente, a introdução de uma comissão de peritos (no vestibular da UnB, junho de 2004), que tem como tarefa avaliar, a partir de análises de fotografias dos candidatos, se estes pertencem - sim ou não - ao "grupo negro", causou um certo mal-estar e até revolta no meio de alguns intelectuais ${ }^{10}$. É no mínimo curioso que, embora haja uma ampla aceitação da tese de que a ciência já comprovou não existirem métodos científicos que permitam definir "raças humanas", procura-se, numa instituição acadêmica, fazer exatamente isso. Mesmo que os defensores do "discurso da racialização" ("bipolaridade racial”) não sejam diretamente responsáveis pela implementação desse método (há entre eles também críticos à instauração desta comissão), a idéia de que seja possível discernir objetivamente negro de branco condiz com o instrumental analítico-conceitual objetivista usado pelos Estudos das Relações Raciais.

É que nesta linha de argumentação há uma tendência implícita (e, por vezes, explícita) de tratar a variedade e o uso flexível de denominações de cores de pele usadas no cotidiano (ou seja, identificações com cores além de branco e de negro) como um não-reconhecimento da realidade ou como expressão de uma "falta de consciência". Assim, o historiador C. Moura, p. ex., já distinguia entre identidades "reais" e identidades "simbólicas e deformadas" (Moura, 1994: 157). Diante do resultado da pesquisa PNAD-1976, que levantou 136 termos de identificação de cores de pele

10. Para P. Fry, veemente crítico do projeto de cotas, a instauração de comissões como esta era previsível: "uma conseqüência lógica de uma política que exige a definição dos candidatos em duas categorias raciais estanques". E termina seu fervoroso artigo com as seguintes palavras: "Essa eventualidade estava previsível desde o início da discussão. Os entusiastas das cotas que lamentam a decisão da UnB não devem ficar surpreendidos, apenas arrependidos!” ( $O$ Globo, 14 abr. 2004). 
diferentes, Moura lamentou: "o brasileiro foge da sua realidade étnica, da sua identidade, procurando, através de simbolismos de fuga, situar-se o mais próximo possível do modelo tido como superior" (Moura, 1988: 63; grifo meu; cf. tb. p. 62). Numa reflexão semelhante sobre a validade de usos das categorias, Guimarães chegou a classificar, "a noção nativa de "cor" como "falsa" para opor-lhe a "categoria correta", isto é, a "raça” (Guimarães, 1999: 43).

Percebe-se que nesta tradição intelectual não se diferencia claramente entre "categorias êmicas" (discursos nativos) e "categorias éticas" (plano analítico) - uma precondição fundamental para analisar, de forma mais aprofundada, a dimensão ideológica de diferentes usos locais, grupais e individuais de categorias identitárias (Cf. tb. a crítica feita por Fry; 1995-1996: 125) e, vinculado a este fenômeno, de mudanças semânticas que podem ocorrer (e ocorrem) ao longo do processo histórico -, mas apos22 ta-se unicamente na elaboração de "explicações sistêmicoracionais” para justificar a redução das múltiplas categorias identitárias usadas no cotidiano a uma oposição entre "brancos" e "negros".

Chama a atenção o fato de que os pesquisadores brasileiros que seguem a orientação básica dos Estudos das Relações Raciais tendem a não relevar as críticas levantadas por toda uma "nova geração" de sociólogos (com inspiração marxista) que têm alertado para os perigos de processos de “essencialização" (cf. os comentários de Guimarães a respeito das reflexões de R. Miles e de P. Gilroy - Guimarães, 1999: 24-25 e 2002: 48-49). Alguns estudiosos associados aos Cultural Studies, como S. Hall e P. Gilroy, têm criticado especificamente o "essencialismo negro". Escreve Hall: "Não existe garantia, quando procuramos uma identidade racial essencializada da qual pensamos estar seguros, de que esta sempre será mutuamente libertadora e progressista em todas as outras dimensões" (Hall, 2003: 347). Segundo Hall, 
formas essencialistas de discursos políticos e culturais descontextualizam e naturalizam a diferença.

E já faz algum tempo que Miles adverte para o fato de que a Sociologia das Relações Raciais tem contribuído para reificar a noção de raça. Ele se pronuncia explicitamente contra o uso analítico da categoria "raça" e propõe, em vez de estudar "relações raciais", analisar o fenômeno do racismo, que ele entende como um fenômeno ideológico, e, mais recentemente também, como uma forma de discurso (cf. Miles, 1993: 1-8; Miles e Torres, 1999: 33, cf. tb. Miles e Brown, 2004: 4-10, 91-92).

Guimarães e outros adeptos das premissas teóricas da Sociologia das Relações Raciais insistem, porém, no uso do conceito de "raça”. Às vozes críticas, Guimarães diz o seguinte: “'raça' é não apenas uma categoria política necessária para organizar a resistência ao racismo no Brasil, mas é também categoria analítica indispensável: a única que revela que as discriminações e desigualdades que a noção brasileira de 'cor' enseja são efetivamente raciais e não apenas de 'classe"” (Guimarães, 2002: 50) ${ }^{11}$.

11. Alguns dos estudiosos que, mais recentemente, têm analisado o fenômeno do racismo num contexto mais amplo das transformações econômicas, sociais, históricas e culturais chamam a atenção para a relação entre modernidade e desenvolvimento da idéia de "raça". Assim, Nederveen Pieterse argumenta que a idéia da raça surgiu como uma nova justificativa de discriminação quando a primeira batalha contra a escravidão já tinha sido ganha e, conseqüentemente, a escravidão perdia sua legitimidade social. "Raça' foi a resposta para o 'problema da liberdade'", escreve Pieterse (1992: 63). De forma parecida, Malik tem afirmado que a idéia de raça, como uma categoria biologizada, somente faz sentido num mundo que já aceitou a possibilidade de igualdade e humanidade comum. A idéia da raça teria surgido e se desenvolvido como um argumento que buscava explicar a persistência de divisões sociais numa sociedade que declarava sua crença na igualdade. Foi neste contexto que, segundo Malik, as desigualdades começavam a ser percebidas como "diferenças naturais" (Malik, 1996: 42, 70; cf., tb., Miles, 1999: 11-13 e Fredrickson, 2004: 67). Percebe-se que abordagens desta natureza, que não partem da existência de "grupos raciais fechados", conseguem elucidar as inter-relações entre transformações econômicas e elaboração de ideologias e dão ainda algumas pistas importantes para a reflexão sobre processos identitários (auto-representação). Desta forma, os estudos de Pieterse, Malik, Miles e Fredrickson (com todas as diferenças teóricas que existem entre estes autores) têm conseguido ampliar o leque de análise, comparado com aquele dos Estudos das Relações Raciais, cuja linha de análise continua presa ao estudo das funções e da intensidade do preconceito de um grupo em relação ao outro. 
Sem querer invalidar a proposta política - certamente válida - inerente ao discurso desse pensador, parece-me importante não deixar de refletir, por razões de ordem pragmática (mobilização política, agilização de um projeto político), sobre a história do conceito de raça. O fato de se declarar que "raça" é uma construção social, não purifica o conceito, nem resolve o problema da conceituação. É preciso lembrar que nunca houve consenso em torno da definição da noção de raça: nem hoje ${ }^{12}$ nem em épocas em que "raça" tinha ainda a aura de um conceito científico objetivo. Há, assim, vários "fatos" que suscitam a seguinte dúvida: se o recurso de recorrer à categoria de raça para analisar a questão das discriminações e das desigualdades é, como Guimarães afirma, a única maneira de desvendar o funcionamento do racismo no Brasil ou se é apenas uma maneira possível de abordar a discriminação racial.

Sabemos que o discurso justificatório da escravidão 24 negra prescindiu durante muito tempo de um "discurso racial" e quando o conceito de raça foi se estabelecendo no discurso científico e popular, esta categoria "convivia" com um ideário que visava a transformar negro em branco. Antes de ser descartado primeiro pela Antropologia e depois pela genética, os especialistas debatiam fervorosamente e discordavam não apenas sobre a quantidade de "raças humanas" existentes. Estava também em questão, o que determinava, definia a(s) "raça(s)". A concepção de raça como um conceito estritamente biológico foi se firmando apenas na segunda metade do século XIX e não conseguiu conven-

12. O filósofo e sociólogo alemão, W.D. Hund, constata que existe, entre os especialistas, um consenso segundo o qual "raça" é uma construção social. Mas que não há acordo quando se trata de avaliar se "raça" deve ser entendida como um fato social, como uma construção ideológica, como uma metáfora discursiva, como uma "invenção" ou como algo semelhante, e se a construção de "raças" é um fenômeno tipicamente ocidental ou é um fenômeno universal (Hund, 2003: 12; cf. tb. 1999: 7). 
cer a totalidade dos cientistas (veja o caso do Brasil, onde a idéia do branqueamento se manteve como discurso científico e político hegemônico) (cf. Hofbauer, 1999, 2003). No séc. XVIII, a maioria dos autores entendia que o que causava as diferenças raciais (o que determinava as raças) eram, em primeiro lugar, influências ambientais externas (forças climáticas, geográficas, a alimentação e, por vezes, ainda fatores religiosos-morais).

Há estudos que mostram que, mesmo nos EUA, na cultura popular existia inicialmente uma maleabilidade na "definição racial" (definição da cor de pele), que era acompanhada também por uma certa ansiedade de as pessoas se mostrarem o mais claro possível ${ }^{13}$. E houve também cientistas, como S. Stanhope Smith (1751-1819), que defendiam a idéia de que, sob a influência de um clima mais favorável e da força da civilização cristã-ocidental vigente no Novo Mundo, os negros trazidos da África (the African race) passariam por um processo de "melhoramento" que envolvia, inclusive, o embranquecimento da cor de pele (cf. Bay, 2000: 62-63; Melish, 1998: 149) ${ }^{14}$.

13. Contrariamente a afirmações de muitos autores, durante muito tempo não havia nos Estados do Sul uma "linha de cor" insuperável. Um mulato livre "bemsucedido" podia "passar por branco". Era comum que nos censos oficiais, filhos de mulatos fossem registrados como "brancos". Ao longo do séc. XIX, pôde-se, porém, constatar, pelo menos em algumas regiões do Sul, não apenas um decréscimo perceptível da população mestiça, mas, também, uma redução percentual dos negros na população livre, o que aponta para um processo de diminuição gradual de permissibilidade social ("racial”) (cf. Gary B. Mills, 1981: 29-33). Comenta Mills: "Further indication of the ease with which Anglo Alabama permitted an individual to cross the color line is provided by the population schedules of the federal censuses and by the state censuses as well. In no less than 78 cases on the 1850 and 1860 federal returns, the Alabama enumerators identified a child as White while simultaneously recording one of his parents as a free mulatto. Similarly, on both the state and federal censuses, numerous mulatto households, including those who had resided in a given area for a number of decades and were therefore known within their community, moved in and out of white ranks with considerable frequency, indicating an extremely careless attitude toward white racial purity on the part of the enumerators" (Mills, 1981: 31).

14 Em trabalhos recentes, aliás em geral não lembrados no debate brasileiro, Fre- 
Em segundo lugar, é bom lembrar, e autores como Guimarães estão cientes disto, que a proposta de dividir a população em "negros" e "brancos" expressa uma atitude política. Ela não é uma maneira neutra de "descrever a realidade", mas expressa muito mais um modo específico de olhar para as diferenças humanas. Este posicionamento, que visa - implicita e/ou explicitamente - à formação (afirmação) de grupos com fronteiras fixas não reflete, por enquanto, a auto-representação de uma grande parte da população brasileira, já que, aparentemente, muitos brasileiros não gostam de ter de optar (de uma vez por todas) por uma das duas categorias previstas pelos estudiosos e/ou preferem "cores claras" como termos de autodenominação. Esta intervenção pode ser justificada por um projeto político de combate a discriminações históricas, mas não dissipa advertências feitas por Miles, Gilroy, Hall e muitos outros a respeito da essencialização de identidades.

\section{O olhar antropológico}

Para entender melhor não apenas uma freqüente aversão em relação ao uso do termo "raça”, mas também uma rejeição bastante forte aos projetos de "cotas para negros" em universidades públicas da parte de alguns cientistas, propo-

drickson e outros autores chamam a atenção para o fato de que o "sistema de duas categorias" e "regras rígidas de descendência" não existiam na época colonial e cristalizaram-se apenas em meados do séc. XIX. Fredrickson critica o fato de que os estudos pioneiros tendiam a apresentar uma oposição drástica entre os EUA e o Brasil, no que diz respeito a dois diferentes padrões de preconceito e de relações entre negros e brancos que teriam existido desde os seus primórdios. Segundo este autor, esta concepção terá de ser revista: "The assumption that 'patterns of race' are fixed early and set in stone now seems ahistorical and essentialist" (Fredrickson, 2001: 6). Vários pesquisadores norte-americanos têm chamado a atenção para a importância da atuação dos tribunais no processo da construção da "linha de cor" nos EUA, especialmente no período pós-Abolição. I.H. López caracteriza esta transformação jurídico-social com a expressão "construção legal de raça" (López, 1996: 9, 118ff.). M. Frye Jacobson fala numa "epistemologia legal de raça" (1998: 226). 
nho rever algumas das raízes teórico-conceituais importantes de uma outra tradição acadêmica. Sabe-se que a Antropologia moderna (culturalismo, funcionalismo e estruturalismo) se desenvolveu a partir de uma crítica, de um lado, às assim-chamadas "teorias raciais" e, de outro lado ao evolucionismo clássico. Coube ao antropólogo F. Boas rebelar-se contra o determinismo racial - contra o "valor explicativo totalizante" que se atribuía ao fator "raça" nas análises dos grupos humanos.

Boas, judeu-alemão imigrado nos EUA, empenhou-se pessoalmente no combate à discriminação dos negros na América do Norte e participou também ativamente de campanhas contra a política anti-semita do Terceiro Reich. E foi no contexto da luta política contra o racismo nos EUA e o nazismo na Europa que Boas reivindicava uma separação conceitual rigorosa entre, de um lado, a "raça" (o âmbito biológico) e, de outro lado, o mundo da "cultura", ou melhor, das "culturas humanas".

Baseado em amplos estudos empíricos, Boas mostra não apenas a fragilidade das premissas dos métodos antropométricos mas também a invalidade das tentativas de hierarquizar "raças humanas". No entanto, Boas não abdica do uso do conceito "raça" que, para ele, dizia respeito exclusivamente ao âmbito da herança biológica. Ao mostrar que o mundo da biologia (isto é: a raça) não tem praticamente nenhuma influência sobre o desenvolvimento das culturas, Boas constrói ("conquista”) um "espaço próprio" para se pensar o "mundo da simbolização". Podemos dizer que desta forma Boas, recorrendo a algumas idéias de filósofos alemães, como J.G. Herder (p. ex., cultura, entendida como a expressão do "espírito de um povo"), funda uma referência conceitual importantíssima para as teorias clássicas da Antropologia moderna.

Sua aluna e assistente R. Benedict seguia a separação conceitual entre "raça" e "cultura", elaborada por seu 
mestre. No seu livro Race: Science and Politics (1940), Benedict faz veementes críticas a usos "incorretos" (indevidos) do conceito de "raça", ao mesmo tempo em que afirma enfaticamente a utilidade e a validade desta categoria. "A raça não é uma 'superstição moderna' como dizem alguns igualitários diletantes. É um fato”, escreve (Benedict, 1987[1940]: 124). O problema começa, na visão desta antropóloga, quando as diferenças biológicas inegáveis são usadas como argumento para discriminar grupos humanos. Segundo Benedict, esta atitude constitui uma "superstição”, ou melhor, um dogma que condena um grupo pela sua natureza (pelas suas características físicas) a uma inferioridade tida como inata.

O antropólogo britânico A. Montagu, radicado nos EUA, entendia - de forma semelhante a Benedict - o racismo como uma ideologia. Mas discordava de Benedict no que diz respeito à compreensão do fator "raça". Para Montagu, diferente28 mente de Benedict, "raça” é um mito, um mito perigoso (cf. o título do seu livro publicado em 1942: Man's most dangerous myth: the fallacy of race). Porque o próprio termo "raça", dizia Montagu, já se baseia em concepções errôneas a respeito da realidade. Ele argumentava que são contextos sociais específicos que dividem, segregam as pessoas em classes e castas e é exatamente nestas situações que a "raça" ganha força para explicar e justificar as diferenças (Montagu, 1997: 43) ${ }^{15}$.

Segundo este raciocínio, há uma relação intrínseca entre forças sociais que segregam e esquemas classificatórios que explicam esta segregação. Como para Montagu o significado de uma palavra é a ação que ela produz, ele entende que a palavra "raça” já é - ela própria - um termo

15. Montagu faz esta crítica, pensando na política do Terceiro Reich: "The belief in race, as in Nazi Germany, became a secular religion whose myths recreated reality". E: "In a society that segregated people by caste and class, 'race' was the term that categorized the most visibly distinguishable groups of people" (1997: 43). 
racista. Não apenas porque constitui um erro de raciocínio e de análise da vida social, mas, diz Montagu, porque é uma ameaça à humanidade, uma vez que já causou catástrofes enormes, guerras e extermínios (: 46-47). No fundo, Montagu argumenta aqui - seguindo reflexões teóricas que Boas tinha feito sobre a percepção de cores e de sons - que as classificações culturais agem sobre a maneira como as pessoas percebem a realidade e orientam a maneira como atuar "de forma adequada" neste mundo. A proposta de Montagu de riscar a palavra "raça" do vocabulário (: 107) seria repetida posteriormente por outros cientistas ${ }^{16} \mathrm{e}$, inclusive, incorporada em documentos editados pela UNESCO: por exemplo, no texto Statement on race (1950), que foi elaborado como parte de uma ampla campanha contra o racismo e pelo respeito aos Direitos Humanos, e para o qual Montagu contribuiu de forma decisiva (como relator) ${ }^{17}$. No item 6 deste texto, que foi publicado na renomada revista Man e posteriormente traduzido e editado em mais de 18 países, propõe-se explicitamente a substituição do conceito de raça por "grupo étnico".

16. Já em 1935, Huxley e Haddon criticavam o uso da palavra "raça" e propunham substituí-lo por "grupo étnico". No livro "Racism" (1938; manuscrito em alemão de 1933-1934), Hirschfeld tinha articulado a mesma proposta (cf. Miles, 1992: 5860; Fredrickson, 2004: 165). Já foi comentado que, mais recentemente, o sociólogo britânico Miles tem feito ataques explícitos ao conceito de raça: ele reconhece que, em muitos lugares, a idéia da raça continua tendo um papel importante no dia-a-dia das pessoas, mas, diz ele, isso não justifica usar "raça" como um conceito analítico. Ao contrário, Miles reivindica que os cientistas sociais deveriam se empenhar em desenvolver concepções teóricas que possibilitem "romper totalmente com a linguagem reificada do essencialismo biológico" (Miles e Torres, 1999: 33). É que, segundo ele, incorporar "raça" como conceito analítico ao discurso antiracista, contribuiria, em última instância, a promover a idéia de que raças existem, de fato, como categorias biológicas de pessoas. É dentro desta perspectiva que Miles fez o seguinte apelo: "[race is] an idea that should be explicitly and consistently confined to the dustbin of analytically useless terms" (Miles, 1992: 97).

17. Participaram da formulação deste documento ("Statement on race") vários antropólogos renomados da época, entre eles: C. Lévi-Strauss, M. Ginsberg, F. Frazier, além de Montagu, a quem coube fazer a última revisão do texto. 
Argumenta-se que grupos nacionais, religiosos, geográficos, lingüísticos e culturais não coincidem necessariamente com "grupos raciais" e que os traços culturais destes grupos não têm conexão genética intrínseca com traços raciais: "Because serious errors of this kind are habitually committed when the term 'race' is used in popular parlance, it would be better when speaking of human races to drop the term 'race' altogether and speak of ethnic groups" (UNESCO, TRC, 1952, p. 99 ${ }^{18}$. Percebe-se, portanto, que o esforço acadêmico-político de reduzir o conteúdo semântico do velho conceito modelar de raça à esfera biológico-genética, e de mostrar que "ódio racial" não é um sentimento inato do ser humano, e sim se baseia em "idéias cientificamente falsas" e é "alimentado pela ignorância” (UNESCO, TRC, 1952: 5), foi acompanhado pela propagação de novas idéias paradigmáticas a respeito das "diferenças humanas": "grupo étnico" e "cultura(s)".

30 Pode-se notar que as três grandes escolas da Antropologia moderna (culturalismo, funcionalismo, estruturalismo), que dominariam a Antropologia do século XX, compartilham, com todas as diferenças que existem entre elas, esta

18. Nem todo mundo concordou com esta posição. Num primeiro momento, alguns cientistas, sobretudo cientistas naturais, negaram-se a invalidar, totalmente, o conceito de raça (reduzir o conceito de raça a uma "entidade imaginada") e propuseram uma espécie de "reforma" da idéia de raça. Geneticistas como Dunn e Dobzhanksy, que, aliás, tiveram participação decisiva na formulação de um segundo documento da Unesco ("Statement on race and racial differences", junho de 1951), admitiam a dificuldade de traçar limites claros entre grupos raciais, rejeitavam explicitamente "a velha noção de raça baseada na teoria de hereditariedade de "sangue'"; no entanto, propuseram redefinir a raça como "populações que diferem pela freqüência da ocorrência de determinado gene ou genes" (Dunn e Dobzhansky, 1946: 101; 110). Sabemos que, posteriormente, geneticistas como Jacquard, Cavalli-Sforza, Marshall e Templeton mostrariam que o conceito de "raça", mesmo quando usado como uma categoria estritamente genética, não corresponde a nenhuma "realidade" observável no mundo da empiria (cf. tb. Santos e Maio, 2004). Assim, a própria genética proclamaria a invalidade do conceito de raça para descrever diferenças genéticas entre seres humanos (cf., p.ex., os estudos de Lewontin, 1972; Jacquard, 1978, Cavalli-Sforza, 1993; cf. também os estudos genéticos efetuados no Brasil por Sérgio Pena, 2000). 
base conceitual comum: ao romper com o biologismo e com os grandes modelos esquemáticos evolutivos do século XIX, criaram e solidificaram uma noção sistêmica de cultura. Os antropólogos dedicar-se-iam ao estudo de padrões culturais ou estudariam funções sociais (culturais), ou ainda estruturas. Estabeleceu-se uma noção de cultura que insinua unidade, coerência, estabilidade e homogeneidade de comportamento e de pensamento dentro de um grupo específico ${ }^{19}$. E, mais do que isto: as concepções objetivistas, embutidas nas três grandes tradições clássicas, sugerem também a existência de uma correlação intrínseca entre as fronteiras de um grupo (fronteiras étnicas) e fronteiras do mundo dos símbolos e valores (fronteiras culturais).

Não é de estranhar, portanto, que questões como "dinâmica das relações sociais", "conflito" e "poder" não façam parte das monografias clássicas em Antropologia. Reflexões teóricas sobre temas como estes começaram a ser desenvolvidas relativamente tarde, num momento, aliás, em que as administrações coloniais enfrentavam sérios problemas com populações locais (cf., p.ex., os estudos de Evans-Pritchard entre os Nuer). Mais tarde ainda, no final da década de 1960 do século XX, aparece um novo conceito analítico importante que se estabeleceria lentamente no vocabulário antropológico. Pesquisadores como o norueguês Fredrik Barth sentiram que a idéia da "cultura" não dava conta de analisar todos os dinamismos que se observava no mundo empírico. Percebeu-se que, em muitos casos, as fronteiras das culturas não coincidiam com as fronteiras grupais. $\mathrm{Ou}$ seja, descobriu-se que é perfeitamente possível que grupos de pessoas compartilhem os mesmos "valores culturais" (que tenham a mesma língua, mesma religião etc.) e que, no entanto, "sintam-se" diferentes um do outro. Como é

19. Cf. também as críticas mais recentes dos assim-chamados antropólogos (p.ex. Lutz e Abu-Lughod, Clifford). 
possível também que exista uma diferença "real" em termos de "produção cultural" sem que isto cause a formação de "identidades" diferentes.

Como um dos primeiros pesquisadores a fazer tal crítica, Barth sustentou que o "grupo étnico" não deve ser visto meramente como "um suporte de uma cultura específica" ("culture bearing unit"). Na introdução do livro Ethnic groups and boundaries (1969), Barth chama a atenção para o fato de que não são "diferenças objetivas" que fazem com que os seres humanos criem diferentes "grupos étnicos". Ele mostra que são sempre apenas alguns signos, alguns "traços diacríticos" (p.ex., a linguagem, a vestimenta, o uso de penteado específico, ou, poderia ainda ser também a cor de pele ${ }^{20}$ que são escolhidos como "emblemas de diferença", enquanto outros traços são ignorados. E é por meio destes "emblemas de diferença", por meio destes signos, que as pessoas constroem, afirmam, frisam e exibem uma "identi32 dade comum".

Mesmo que haja várias abordagens e vários usos diferentes do conceito de "identidade", pode-se afirmar, acredito eu, que, genericamente falando, a introdução da idéia da "identidade étnica" nas análises antropológicas tem permitido pensar melhor o lado subjetivo dos processos socioculturais, uma vez que a noção de "identidade" direciona a análise para opções, para escolhas mais ou menos conscientes dos indivíduos e dos grupos. Entretanto, chama a atenção a grande quantidade de abordagens teóricas que se propõem, por vezes de forma muito sofisticada e eclética, a explicar como "identidades étnicas" são construídas,

20. Alguns autores, como T. Hylland Eriksen, diferenciam entre identidades mais ou menos "imperativas" e identidades escolhidas mais ou menos livremente. Mas mesmo no caso de processos de identificação mais impositivas (como exemplos, Eriksen cita identidades ligadas ao parentesco, à língua-mãe, à questão do gênero, idade), Eriksen destaca a possibilidade de negociações e de manipulações (1993: 54ff.; 2004: 163). 
manipuladas, negociadas etc., sem, porém, incluir na sua fundamentação teórica, de forma explícita, questões ligadas a "relações de poder", desigualdade socioeconômica e discriminação.

Na sua livre-docência, a antropóloga alemã B. Beer analisa e critica que, desde a separação conceitual entre cultura e raça (primeiramente articulada por Boas), os antropólogos começaram a abandonar o tema do racismo, muito caro a uma primeira geração de antropólogos, entregando este campo de pesquisa a outras áreas de conhecimento. Beer vê uma relação entre o abandono da reflexão sobre o racismo na sociedade ocidental e uma certa tabuização de alguns temas, como "etnocentrismo", em estudos sobre sociedades não-ocidentais. Não tem sido de bom tom, diz ela, investigar se culturas não-ocidentais valorizam ou depreciam determinados fenótipos, determinadas tonalidades de pele, ou outras características físicas (Beer, 2002: 15). Pouco se discutiu a questão de aspectos físicos como possíveis "marcadores de fronteiras" ("boundary markers").

Tudo indica que a maneira como o conceito de raça foi "expurgado" da reflexão antropológica - fazendo-se questão de desqualificar os velhos ideários ligados à "raça” como “erros", "nonsense", como "idéias falsas" etc. ${ }^{21}$ - tem contri-

21. Partindo de uma outra perspectiva teórica, Miles chama a atenção para o fato de que muitos dos estudos críticos do racismo têm se concentrado no estudo de textos científicos, sem analisar como as representações são criadas e reproduzidas no cotidiano das pessoas. Segundo este autor, a redução do fenômeno do racismo a uma "falsa doutrina" (cf., p.ex., discurso assumido nos textos da UNESCO) faz com que se perca de vista que o racismo tem tanta eficácia porque faz sentido para as pessoas que se apóiam nestas idéias (estereótipos) (Miles e Brown, 2004: 105). F. Harrison (1995) entende que, ao longo do séc. XX, ocorreu na pesquisa antropológica um deslocamento do interesse da idéia de raça para a idéia de etnicidade: "Critiques of race as a biological concept led many anthropologists to adopt a 'no-race' position that was not adequately followed by research designed to answer the simple question: Why does racism continue to exist if there are no races in the natural world? With race's decline as a conceptual and analytical category, ethnicity, [...] became the master principle of classification" (apud Beer 2002: 368). 
buído para o fato de que depois da Segunda Guerra Mundial muitos estudos antropológicos tenham evitado abordar a relação entre "o físico" e "o cultural" 2 . Ou seja, pode-se concluir da argumentação de Beer que o fortalecimento das categorias analíticas de cultura, e posteriormente de identidade (etnicidade), como esferas totalmente independentes de fatores biológicos, levou a maioria dos antropólogos a se distanciar do conceito de raça (“"no race stance' position”). E mais: desestimularia também a produção de conhecimento teórico sobre o fenômeno do racismo.

Diferentemente da tradição da Sociologia das Relações Raciais que parte, nas suas considerações, da existência de dois grupos raciais, em muitos dos estudos desenvolvidos no Brasil, que se orientam pelos métodos e pelas concepções teóricas clássicas da Antropologia Social e Cultural, podemos perceber uma tendência de abordar as "relações raciais" a partir de um "estilo de vida brasileiro", tido como único.

Mesmo que o objetivo dos pesquisadores certamente não seja o de defender uma ideologia repressora, a primazia atribuída ao mundo simbólico em detrimento de outros fatores lhes vale, por vezes, críticas bastante ácidas: elas vão desde acusações como a de reproduzir o pensamento de G. Freyre até imputações tais como a de defender privilégios dos brancos e dificultar a implementação de medidas políticas efetivas de combate ao racismo.

Não é por acaso que Freyre é lembrado freqüentemente no calor do debate. Mesmo que este pensador não tenha cumprido completamente sua própria proposta metodológica de seguir Boas, ou seja, de deixar de lado hierarquizações raciais/culturais e de diferenciar claramente entre

22. Mais recentemente, podemos perceber uma certa recuperação desta temática sob a ótica dos estudos sobre a corporalidade que têm conseguido conquistar um espaço próprio dentro da Antropologia. No entanto, a maioria destes estudos são guiados por outras preocupações teóricas e dão um outro enfoque àquelas questões (poder, ideologia, discriminação) que estão no centro das pesquisas sobre o racismo. 
âmbito biológico e âmbito simbólico ${ }^{23}$, a inspiração boasiana ajudou Freyre a criar uma nova imagem, uma espécie de mito de origem de uma nova nação nos trópicos: em Casa grande e senzala, ele constrói os alicerces da idéia de que existe, de fato, uma "cultura brasileira", produto de um amalgamento de diferentes "raças"/"culturas", que constituiria a "essência" de uma nova nação.

Ao destacar as diferentes contribuições positivas das três "raças" /"culturas" fundadoras, e ao descrever tanto a casa grande e a senzala como as figuras do senhor e do escravo como "dualismos complementares", Freyre não apenas recria e solidifica concepções essenciais da noção clássica de cultura (presente no culturalismo, mas também no funcionalismo e estruturalismo), mas fundamenta, implicitamente, também, a famosa idéia da "democracia racial"24.

Nesta imagem de uma - supostamente harmoniosa fusão entre negros, brancos e índios (tanto em termos biológicos, como em termos culturais) não cabiam questionamentos a respeito de relações de poder, conflitos de interesse ou ainda temas como exploração econômica. Não é um acaso que a "mestiçagem" ocupe um lugar central na argu-

23. Gilberto Freyre declarou-se expressamente seguidor das idéias de Boas, com quem teve aulas na Universidade de Columbia. No prefácio (primeira edição) de sua obra-prima, Casa-grande $\mathcal{E}$ senzala (1933), Freyre afirma que a diferenciação conceitual boasiana entre raça e cultura, "entre os efeitos de relações puramente genéticas e os de influências sociais, de herança cultural e do meio" (Freyre, 1992: XLVII, XLVIII), constituiriam a orientação teórica de suas reflexões: "Neste critério de diferenciação fundamental entre raça e cultura assenta todo o plano deste ensaio", escreve (: XLVIII). Freyre não abriu, porém, mão totalmente de concepções hierarquizadas no que diz respeito à análise das diferenças humanas. Assim, ele fala freqüentemente de "raças chamadas superiores", "raças chamadas inferiores", mas também de "culturas adiantadas", "povos atrasados" etc. (p. ex. 1992: 109, 189). Cf. ainda a seguinte frase: "A formação brasileira foi beneficiada pelo melhor da cultura negra da África, absorvendo elementos por assim dizer de elite que faltaram na mesma proporção ao Sul dos Estados Unidos" (: 299, 300).

24. Embora Freyre não tenha cunhado o termo de "democracia racial" (cf. tb. Guimarães, 2002: 141ff.) e concepções parecidas já tenham sido articuladas antes dele no discurso abolicionista (p.ex., Nabuco), ele foi certamente o cientista que mais contribuiu para consolidar e divulgar este ideário. 
mentação deste autor. A mestiçagem teria cumprido uma espécie de "ponte" capaz de aplainar e superar os desajustes entre negros, brancos e índios e, desta forma, teria viabilizado a formação da "nação/cultura brasileira". Assim, na análise de Freyre, o mestiço aparece quase como uma prova da - postulada - convivência harmoniosa entre as raças.

Dentro desta perspectiva, Freyre criticava veementemente, ainda no final da década de 1970, não apenas a reintrodução dos itens de cor nas pesquisas demográficas do IBGE, mas também a formação de movimentos negros. Freyre pronunciava-se veementemente contra a idéia de que existisse “um 'negro brasileiro' à parte da comunidade nacional brasileira", como, segundo ele, diziam os militantes negros nos seus protestos. É que para ele a miscigenação ocorrida neste país era tão intensa que se tornava impossível enquadrar as pessoas "em dois ou três ou quatro categorias fixas” (Folha de S.Paulo, 6.5.1979 e 5.12.1979). Afirmar a exis36 tência de um grupo negro autônomo ia contra a construção analítica de Freyre que apostava na consolidação de uma "meta-raça" que o autor via diretamente ligada à existência de um "etos" (cultura) brasileiro próprio, concebido como uma espécie de totalidade orgânica, uma entidade coesa e homogênea.

Em vários discursos que comentam o projeto de "cotas para negros" com preocupação, alertando para um possível acirramento de conflitos entre brancos e negros e/ou condenando abertamente esta medida política, podemos perceber não exatamente uma cópia do discurso de Freyre, mas igualmente uma tendência de privilegiar, na argumentação, o mundo simbólico em detrimento da questão da desigualdade social. E pode-se verificar também uma tendência de subordinar a análise de "categorias identitárias" (categorias que traduzem "pertencimento" e "delimitações grupais") - e, com isto também, as relações entre os grupos - à existência de um "etos específico" que seria incorporado por todos os brasileiros. 
Ao comparar a questão racial no Brasil com a situação nos EUA, R. Da Matta, que não se pronunciou contra o projeto de cotas, mas cujas idéias têm sustentado o discurso anticotista, afirma, entre outras coisas, o seguinte: "O problema básico [...] - sem o qual a questão racial não pode ser entendida -, jaz no estilo cultural por meio do qual as duas sociedades elaboram, constroem e lidam com as suas diferenças" (Da Matta, 1997: 71-72). Da Matta chama ainda a atenção para o fato de que, diferentemente do sistema racial bipolar dos EUA, que define o mestiço como "negro", no Brasil as relações sociais são dominadas por "uma ideologia de mistura e ambigüidade" que faz com que o mestiço simbolize "integração". E usa conceitos como "insegurança classificatória” e "indeterminação étnica” para explicar o fato que, no Brasil, “[p] essoas ficam 'brancas' ou 'negras' de acordo com suas atitudes, sucesso e, sobretudo, relacionamentos" (: 72-73).

O modo como categorias-chave como "negro", "branco", "raça" etc. são tratados em trabalhos de cunho antropológico que se propõem a abordar a questão racial revela, a meu ver, a força de referenciais teóricas clássicas - sobretudo do estruturalismo lévi-straussiano. Fala-se, nestes estudos, correntemente de "sistemas classificatórios", cuja origem raras vezes é explicada e cujo "funcionamento" é analisado freqüentemente numa esfera que se localiza além dos processos históricos concretos e além das preocupações e intenções subjetivas dos vários agentes sociais. Argumentase que existe no Brasil algo como uma "estrutura" própria (um sistema classificatório ${ }^{25}$ ) ou um "etos" que privilegia os

25. Termos como "sistema de classificação (da cor)" aparecem também nas reflexões de outros estudiosos da questão racial, como nos trabalhos de Da Matta (1997: 71), de L. Schwarcz (1995: 60), mas também naqueles de L. Sansone (1996: 169) cuja orientação conceitual-teórica certamente não segue modelos antropológicos clássicos. No seu mais recente livro Negritude sem etnicidade (2004), Sansone busca desenvolver novos caminhos teóricos, inspirados nos Cultural Studies, para analisar a questão racial no Brasil. 
meios-tons e as ambivalências e que rejeita fronteiras rígidas entre "branco" e "negro".

Assim, nas reflexões de Y. Maggie, por exemplo, as diferentes denominações de cor tendem a ser tratadas como significantes que apontam para uma estrutura profunda, uma espécie de "lógica oculta" que se expressaria na "cultura brasileira", como se pode perceber na seguinte passagem: "Essa categoria [moreno] é como uma chave para se falar em cor e raça sem falar de cor e raça, pois moreno contém em si mesmo tanto cor, como ausência de cor [...]. Moreno contém em si o gradiente, a oposição negro/branco e a oposição preto/branco. Ela é a categoria que por excelência fala do nosso modo particular cotidiano de falar nas raças e nas oposições, sem falar delas" (Maggie, 1996: 231-232) ${ }^{26}$.

A perspectiva objetivista embutida na tradição estruturalista clássica não estimula indagações a respeito de inten38 cionalidades subjetivas ligadas ao uso das categorias ou ainda a respeito de transformações e variações semânticas dos conceitos que se manifestam em meio a conflitos de interesses. Trabalhos estruturalistas clássicos tendem a não explorar a dimensão política que o conceito de identidade oferece, uma vez que privilegiam o esforço de "decodifica-

\footnotetext{
26. Ou ainda: "O moreno é a metonímia por excelência porque o termo pode ser usado para falar dos três domínios de classificação. Moreno é preto, mas também branco de cabelo escuro. Moreno é preto, mas também pardo ou preto mais claro. A categoria moreno revela também a cultura" (Maggie, 1996: 233). Cf. também como L. Schwarcz analisa a categoria de mestiço: "O mestiço surge, dessa maneira, constantemente reinvestido como espaço da ambigüidade, suporte de representações. Intermediário entre negro e branco, o mestiço talvez seja mesmo uma categoria "boa para pensar'". E continua: "Parafraseando o modelo de Lévi-Strauss, seria possível fazer um paralelo entre o mestiço e certos animais considerados tabu em suas sociedades. No sistema de classificação de tais culturas, esses animais ocupam um lugar sempre intermediário, que põe em risco uma certa ordem que os orienta (Lévi-Strauss, 1970). Com efeito, pensado como um problema, como um fator de degeneração da raça, no final do século XIX, eis que o mestiço é reinventado nos anos 30 como produto nacional [...]" (Schwarcz, 1995: 60).
} 
ção gramatical" que visa a estabelecer relações lógicas no plano da estrutura ${ }^{27}$.

Antropólogos importantes da atualidade, como Da Matta, mas também Fry ou ainda L. Schwarcz, costumam dizer que, mesmo que o "mito da democracia racial" não corresponda à realidade, este mito - por si só - constitui um ideal, um valor social para a maioria da população brasileira. Por isso, segundo Schwarcz, por exemplo, não adianta, não basta "desmascarar" a "democracia racial" como uma "falsa ideologia", como teria feito Florestan Fernandes e seus seguidores. É preciso "levar a sério" os mitos (cf. Schwarcz, 1998: 236; Fry, 1995-1996: 134). É que, segundo Schwarcz, "a oportunidade do mito se mantém, para além de sua desconstrução racional, o que faz com que, mesmo reconhecendo a existência do preconceito, no Brasil, a idéia de harmonia racial se imponha aos dados e à própria consciência da discriminação" (Schwarcz, 1999: 309)28. E noutro lugar: "O 'mito da democracia racial', como bom mito, contém distorções na igualdade absoluta que anuncia, mas possui verdades parciais ao indicar uma singularidade no relacionamento entre as raças" (Schwarcz, 1996: 154).

Reflexões antropológicas como estas têm oferecido pistas importantes para se entender melhor a dinâmica e as ambigüidades que marcam a questão complexa das iden-

27. Num seminário sobre "Identidade", em 1977, Lévi-Strauss desqualificou, até certo ponto, a importância da questão da identidade. Ele não nega que possa ser útil usar o conceito para "explicar um certo número de coisas"; mas, segundo ele, não contribui para a análise estrutural. Diz o pensador francês: “[...] L'identité est une sorte de foyer virtuel auquel il nous est indispensable de nous référer pour expliquer un certain nobre de choses, mais sans qu'il ait jamais d'existence réelle". E: “[...] je me demande jusqu' à quel point cette unité que l'on postule correspond d'une façon quelconque à quelque chose de réel" (Lévi-Strauss, 1977: 331-332).

28. Schwarcz refere-se aqui explicitamente às idéias de Lévi-Strauss, quando diz: "[...] tomando os termos de Lévi-Strauss, [poderíamos] dizer que o mito se extenua sem por isso desaparecer" (Schwarcz, 1999: 309). 
tidades no Brasil. Mas, ao tratar "categorias identitárias" como significantes de estruturas ocultas, tende-se, freqüentemente, a esvaziar a semântica política das categorias-chave em questão (negro, branco, raça etc.). Na medida em que não se procura estabelecer relações (funcionais ou causais) entre "estruturas", "sistemas classificatórios", de um lado, e outros dados importantes (tais como relações econômicas e de poder) da vida social, torna-se difícil desenvolver uma análise da discriminação racial que não esteja diretamente vinculada ou permeada pelo imaginário contido nos "mitos sociais". Ou seja, na medida em que as análises tendem a abordar a construção da(s) diferença(s) separadamente da construção da desigualdade, elas correm o perigo de se transformar em discursos justificatórios dos mitos sociais.

Assim, antropólogos renomados, como Maggie e Fry, têm argumentado nas suas críticas veementes contra a implantação de cotas em universidades públicas que medi40 das como estas ameaçam a maneira como os brasileiros pensam as diferenças. E ainda pior: trazem em si o potencial de introduzir o conflito racial na sociedade ${ }^{29}$. "As conseqüên-

29. "Introduzindo o racismo" é o título que Fry deu a um artigo em que o autor reflete sobre as possíveis consequências do "projeto de cotas" (O Globo, 21/03/2003). O historiador R. Pinto de Góes (UERJ) avalia também que o projeto de "cotas para negros" rompe com uma longa tradição jurídica. Ele afirma que as Constituições brasileiras (inclusive, a última de 1988) referem-se à "raça" exclusivamente para desqualificar esta idéia. E entende que o Estatuto da Igualdade Racial (no qual a implementação de cotas está previsto) "legitima a idéia de raça como um critério de distinção entre as pessoas, e isto", diz Góes, "é racismo" (Jornal da Globo News, 26/03/2004). Góes, como também M. Grin, reagiram fortemente à introdução de uma comissão de peritos que deve averiguar o pertencimento ao "grupo racial negro" no vestibular da UnB, chamando-a de "tribunal de pureza racial" (Góes, apud O Estado de São Paulo, 13/04/2004; Grin: entrevista dada para o Jornal da Globo News, 26.3.2004). Ao mesmo tempo, Góes nega que, na história do Brasil, o racismo tenha sido "um elemento estrutural na recriação da desigualdade". Ele reconhece apenas a existência de atitudes racistas individuais ("sempre haverá pessoas pouco razoáveis”). Baseado em seus estudos históricos e comparando o caso dos EUA com aquele do Brasil, Góes avalia que "a escravidão no Brasil não possuía a mesma conotação racial que possuía nos Estados Unidos”. Não precisava ser branco para ser senhor de escravo, analisa o historiador. "Talvez por isso lá existe um problema racial, e aqui não” ( $O$ Globo, 14.12.2001). 
cias do sistema de cotas são muito danosas para nossa cultura, que baseia nossa identidade na mistura”, afirma Maggie numa entrevista concedida à Folha Dirigida, em 2002. E continua: "Isso vai mudar radicalmente, no momento em que você pode ganhar coisas se definindo como negro, você não vai querer ser misturado. A disputa entre negros e brancos vai aumentar. Outro problema que vejo é que ela marca a pessoa para o resto da vida. Ela [a pessoa] entrou pela reserva e não no vestibular como todo mundo, que era o grande trunfo dos vestibulandos negros e carentes" (Folha Dirigida, 17.9.2002).

Num artigo escrito conjuntamente, que se baseia na análise de opiniões expressas em cartas de leitores publicadas no jornal $O$ Globo, Maggie e Fry são muito enfáticos em afirmar que a política de ações afirmativas provocará um rompimento com "o a-racismo e anti-racismo tradicionais” (Maggie e Fry, 2002: 94, 96). Não é que estes autores não reconheçam que exista um "problema racial" no Brasil. Usam freqüentemente até o mesmo termo - "racismo" - para se referir a esta problemática.

Agora, essa aparente contradição (ou confusão no uso dos termos) pode ter a ver também com uma certa despolitização presente na maneira como a questão da diferença tem sido abordada pelas teorias clássicas em Antropologia, como tentei argumentar acima. De um lado, assume-se aqui, implicitamente, uma "concepção ortodoxa" (clássica) de racismo, tal qual fora formulada a partir da década de 1930 e posteriormente divulgada pela UNESCO em vários documentos, que não corresponde e nunca correspondeu inteiramente aos processos e mecanismos discriminatórios no Brasil, sem, porém, chamar a atenção para o contexto histórico em que o conteúdo desse conceito foi elaborado; e, de outro lado, não se problematiza o que seria o "racismo brasileiro".

Maggie e Fry entendem que a implantação de "cotas para negros" promove a idéia de que existem raças. Afir- 
mam que "um sistema de cotas implica logicamente a criação de duas categorias 'raciais'" (Maggie e Fry, 2002: 98), o que para eles é sinônimo de promoção do racismo. E a rejeição dos dois antropólogos é categórica: "Não se vence o racismo celebrando o conceito 'raça', sem o qual, evidentemente, o racismo não pode existir" (: 106, grifo meu).

Numa entrevista ao jornal A Favela, esta postura de Fry torna-se ainda mais clara. Quando o entrevistador questiona se a posição do antropólogo sugere "que é melhor não mexer no problema”, Fry responde da seguinte maneira: "Eu não disse isso. É claro que o Brasil precisa enfrentar o seu racismo. E é bom definir o que é racismo. Não é a desigualdade racial. É a crença na existência de diferenças morais e intelectuais baseadas na aparência física. É preciso combater a crença de que existem raças e de que umas raças são superiores às outras. Se adotar um vestibular especial para negros, o Brasil estará oficializando o reconheci42 mento de raças" (A Favela, 04/09/2001). Chama a atenção o fato de que Fry faz questão de dissociar "fatos concretos" (a desigualdade) do "mundo das idéias" (ou de ideologias) para definir o que ele entende como racismo. E a ênfase recai sobre a produção do ideário e não sobre a realidade discriminatória.

\section{Considerações sobre 0 racismo}

Para situarmos melhor afirmações como essas no debate acadêmico, parece-me importante lembrar as análises de Miles e de P.-A. Taguieff, teóricos da questão do racismo, que chamaram a atenção para o contexto em que o conceito de racismo foi cunhado. Eles mostraram que o termo "racismo" surgiu apenas na década 30 do século XX, e serviu, inicialmente, muito mais como um "conceito de luta" do que como um "instrumento analítico" (cf. Taguieff, 1998: 227 e Miles, 1992: 58-59). Sua propagação visava a denunciar formas específicas de discriminação que se pautavam por 
leis específicas e por concepções biologizadas de raça (em primeiro lugar, a "política racial” do regime nazista).

Esta concepção de racismo seria, posteriormente, amplamente discutida e continua sendo objeto de discórdias acadêmicas. Assim, vários especialistas no assunto têm optado por um "uso dilatado" do conceito para poder incluir formas de discriminação que não se prendem diretamente à noção biologizada de raça. Há também um debate acadêmico de longa data a respeito da origem, da delimitação histórica desse fenômeno social. Um grande número de autores, como R. Sanjek, entendem o racismo como uma "invenção" européia, vinculada ao colonialismo e ao desenvolvimento da escravidão moderna (cf. Beer, 2002: 46, 54). Alguns autores afirmam explicitamente que antes do século XV não teria existido uma "consciência racial” (p.ex., Linton - in Beer, 2002: 258) ${ }^{30}$.

Já faz algum tempo que vários pesquisadores chamaram a atenção para o fato de que, sobretudo no contexto europeu, idéias como "raças biologizadas" são cada vez menos usadas para justificar atos discriminatórios. Assim, a "Nova Direita” na França e outros grupos xenófobos na Europa têm reivindicado a introdução de direitos específicos para preservar a "cultura nacional" e a "identidade nacional",

30. Pierre L. van den Berghe critica o fato de que, com o decorrer do tempo, o conceito do racismo teria sido tão "dilatado" (expandido) que teria perdido seu valor analítico (in: Beer, 2002: 323). Para pesquisadores como Sanjek (in: Beer, 2002: 54), racismo existe, stricto sensu, apenas naquelas sociedades onde as pessoas acreditam na existência de "raças biológicas", onde há uma ideologia que divide os seres humanos em grupos biologicamente diferentes - ou seja, para estes autores, o surgimento do racismo pode ser datado na história do mundo ocidental. Miles defende um "uso dilatado" da idéia de "construção de raças" (que ele denomina de "racialização" e entende como um processo de classificação) que não se prende obrigatoriamente ao uso explícito, ou seja, à presença da categoria de "raça". Ele argumenta que, já na Antigüidade - ou seja, antes da introdução da idéia de raça - referências a características fenotípicas e a cores de pele eram usadas como "significantes" para constituir "coletividades" (para "construir grupos") (Miles, 1992: 100). 
sem fazer nenhuma referência ao conceito de raça. Taguieff (1998: 236, 237) chamou a atenção para o fato de que a literatura político-filosófica das Nouvelles Droites tem usado citações de autores como Lévi-Strauss e Dumont para legitimar suas reflexões (p.ex.: a idéia da "irredutibilidade dos particularismos culturais").

Ou seja, percebe-se que a aplicação da crença na existência de uma "cultura" e/ou de uma "identidade" particular, entendida como a essência de um povo, pode surtir os mesmos efeitos, ou, no mínimo, efeitos bem semelhantes no que diz respeito a processos de discriminação e de exclusão. Este dado foi percebido por vários pesquisadores que responderam à nova situação com a criação de uma série de neologismos que, para alguns, podem parecer um novo movimento que visa a dilatar a concepção clássica do racismo: Balibar criou o conceito de "racismo sem raças", e usa também o termo "neo-racismo" (este último tem sido usado 44 também por Castles); Fanon, e recentemente também Hall, fala em "racismo cultural"; Essed cunhou o termo "etnicismo racial"; e Taguieff propôs o conceito "racismo diferencial” (cf. tb. Zerger, 1997: 84).

Mais recentemente, Beer mostrou que muitas sociedades não-ocidentais "usam" também características físicas específicas para criar classificações e, inclusive, para justificar hierarquizações sociais. Pautada por esta análise, Beer reivindica que tais fenômenos deveriam ser entendidos também como "construções de raças", ou seja, como formas de racismo. Beer localiza, portanto, uma postura etnocêntrica na maioria dos estudos sobre a questão. No entender dela, seria essa a razão da consolidação de um paradigma de análise que afirma que "racismo" é uma invenção do colonialismo europeu (Beer, 2002: 267). Segundo ela, seria mais frutífero e mais "adequado" procurar a fonte do racismo no fenômeno da dominação, do poder e - deste modo - ver o colonialismo como uma forma específica desse padrão mais genérico. 
Questionamentos como esses a respeito da definição do racismo valem também para o contexto brasileiro. Se partirmos das definições da UNESCO (acima), como aparentemente autores como Schwarcz, Maggie, Fry, Góes e outros fazem, será de fato difícil detectar, de forma clara, quando e de que maneira esse fenômeno se instaurou no Brasil. E a proposta da implantação de "cotas para negros" pode aparecer como uma "medida racista".

É que, como sabemos, durante os primeiros séculos da colonização, a importação de escravos foi sustentada por um discurso de teor basicamente religioso que desconhecia a categoria de raça. Africanos e seus descendentes eram explorados e discriminados sem serem transformados numa "raça" stricto sensu (cf. o discurso jesuítico que propagava o tráfico como um "resgate", ou seja, como uma operação que, segundo eles, visava a "salvar as almas" de "gentes enegrecidas"; Hofbauer, 2003: 70-76). Quando o uso do conceito de raça se estabeleceu no Brasil (no linguajar da elite e também nas camadas populares), a força do ideário do branqueamento (e a ausência de leis segregacionistas) fizeram com que categorias como "negro", "branco" e "raça negra", "raça branca" continuassem a ser tratadas, aparentemente não apenas pelo discurso dominante, como noções não totalmente (coerentemente) "essencializadas".

Agora, não se trata aqui de achar a "melhor", a "mais correta" definição de racismo ou de delimitá-lo de outros fenômenos semelhantes. Concordo com o filósofo e sociólogo alemão Wulf Hund, que reivindica que o fenômeno do racismo não pode ser definido de forma abstrata, mas tem de ser analisado e captado, caso a caso, numa perspectiva histórica. Ao criticar que, no debate internacional atual, tem-se gastado muita energia em tentativas de definir o fenômeno do racismo (Hund, 2003: 12, 19), ele afirma: 
"On that score there is 'a lack of historical reflexivity' not only 'about the historical background to the emergence of modern racism' [...]. It is about racism in general. Up to a point this is a theoretical problem. Far too many studies are concerned with definitions. Yet ideas cannot be defined, they have to be evolved historically" (: 19).

Na medida em que conceitos como "raça", "negro", "branco" atuam como categorias de inclusão e exclusão, que remetem também a concepções de mundo, parece-me importante concebê-los como parte integrante e importante das "histórias particulares da discriminação" e deve-se analisá-los, portanto, dentro de seus contextos econômicos, históricos e sociais específicos. É preciso estudar como se conjugam ideologias, discursos, concepções do mundo (e não apenas os ideários da elite) e condições econômicas e 46 sociais e, desta forma, abordar a problemática da "desigualdade social" e a questão das "especificidades simbólicas/culturais" numa perspectiva integrada.

Numa abordagem que procura evitar o risco de promover concepções essencializadas do mundo (ou de "grupos raciais" ou de "mundos simbólicos") e se propõe a servir também como uma "crítica cultural/social”, não me parece muito adequado tratar a desigualdade sem levar em consideração a diferença, ou vice-versa. É que a força (a "essência") do fenômeno que poderíamos chamar de racismo provém provavelmente da maneira como concretudes e ideários se entrelaçam, ou seja, como "desigualdade real" e "diferença simbólica” são produzidas, articuladas e mescladas pelos atores sociais.

\section{Epílogo: levando críticas sérias a sério}

Não tendo a pretensão de aprofundar a reflexão sobre políticas multiculturalistas e ações afirmativas em si - o que não 
é objetivo explícito deste pequeno ensaio - quero apenas chamar a atenção para algumas questões de fundo que me parecem relevantes. É importante estarmos conscientes do contexto diante do qual fazemos as nossas análises e desenvolvemos nossas reivindicações políticas. Constatamos hoje, no mundo inteiro, o avanço de forças econômicas que tendem a desestabilizar velhas estruturas sociais (e culturais) e põem em xeque várias das velhas funções e dos compromissos sociais tradicionais que o Estado-Nação tem se proposto a cumprir desde as revoluções burguesas.

Assim, em muitos países do mundo (sobretudo naqueles chamados "desenvolvidos"), o Estado começou a abandonar áreas sociais fulcrais, como a saúde e a educação, delegando-as à iniciativa privada; em muitos outros (naqueles freqüentemente chamados "em desenvolvimento"), o Estado, no fundo, nunca conseguiu cumprir satisfatoriamente com esta sua promessa. Parece que o enfraquecimento do Estado nacional e suas instituições representativas clássicas faz com que, cada vez mais, as pessoas se articulem em "grupos de pressão", uns competindo com os outros, para obter certos "benefícios" que antigamente eram tidos como garantias sociais do cidadão.

Em várias partes do mundo, as recentes desestabilizações no plano da organização social, provocadas, em boa parte, por políticas econômicas neoliberais de cunho fundamentalista, têm sido respondidas com fundamentalismos de ordem étnico-religiosa: diante do desmoronamento de velhas supra-estruturas e de antigas garantias, certezas e idéias, as pessoas voltam-se para aquilo que acreditam ainda ser "essencialmente seu" - uma espécie de autodefesa articulada como uma resposta, de certo modo, sistêmica a inseguranças geradas pelas drásticas transformações econômicas e sociais que têm ocorrido em todo o globo. No mundo inteiro, podemos perceber hoje processos de etnicização, erupções de xenofobia e, conseqüentemente, conflitos béli- 
cos e até genocídios. Penso que um discurso reivindicatório crítico que vise, com plena justeza, à implementação de políticas específicas para aqueles historicamente desprivilegiados deve ter em mente esse contexto global e delimitarse claramente de posturas fundamentalistas e xenófobas. Deve-se, sim, a meu ver, ser levado a cabo um esforço para "marcar a diferença".

Num estudo recente, G. Baumann fez as seguintes ponderações sobre projetos multiculturalistas que tendem a se transformar em políticas de afirmação de identidades: a idéia das Ações Afirmativas surgiu inicialmente, segundo ele, para afirmar o igual acesso a direitos civis, buscando, desta maneira, retificar injustiças históricas. No entanto, percebe-se hoje que em muitos lugares do mundo Ações Afirmativas contribuíram para afirmar não a crença nos direitos civis, mas a crença nas comunidades étnicas e religiosas e no direito de cada uma delas determinar o seu pró48 prio destino. Isto não quer dizer que devamos nos opor a qualquer tentativa de implementar Ações Afirmativas. Mas, diz Baumann, temos de ter clareza de que os direitos civis e os direitos comunitários seguem lógicas diferentes e até certo ponto excludentes. Enquanto os direitos civis excluem estrangeiros, direitos étnicos excluem aqueles considerados "não-étnicos" ou "semi-étnicos". O perigo consiste, segundo Baumann, no fato de muitos líderes étnicos (e/ou religiosos) tratarem, nas suas atividades políticas, os dois tipos de direitos como basicamente iguais. Mesmo que haja razões compreensíveis para eles agirem desta forma, esta atitude tende a causar resultados paradoxais e contraproducentes (Baumann, 1999: 4, 9-10).

A maioria dos projetos multiculturalistas baseia-se, em termos teóricos, de forma explícita ou implícita, nas reflexões de C. Taylor e/ou de W. Kymlicka, os quais, como foi mostrado por vários pesquisadores, recorrem a concepções de identidade e de cultura que a Antropologia moderna 
abandonou há várias décadas ${ }^{31}$. Assim A. Reckwitz critica o fato de que uma concepção de cultura inspirada no "modelo de bola" (Herder, mas também Boas) que frisa a delimitação para fora e, ao mesmo tempo, a homogeneidade para dentro, não condiz simplesmente com as experiências de vida das pessoas. Segundo este sociólogo, autor de vários trabalhos sobre "teoria cultural", o normativismo preponderante nas reflexões teóricas de Taylor e de Kymlicka prestase pouco para o desenvolvimento de uma análise sociocultural adequada do mundo atual (Reckwitz, 2000: 503; 2001; cf. tb. Vermeulen e Slijper, 2000). O fato de as teorias normativas multiculturalistas deixarem de (ou até rejeitarem) diferenciar claramente entre cultura e etnicidade foi classificado por Appiah (1997) de o mal-entendido multiculturalista ("the multiculturalist misunderstanding").

T. Hylland Eriksen, especialista em assuntos relacionados a etnicidade e globalização, concorda com esta avaliação crítica das premissas teóricas quando aponta para o seguinte problema: o direito à diferença, da maneira como projetos multiculturalistas o têm propagado, costuma não contemplar o direito a não assumir uma identidade étnica específica ou de optar por mais de uma ao mesmo tempo ou ainda de preferir e viver formas híbridas. E faz o seguinte alerta: "Uma epistemologia que baseia a qualidade de vida do indivíduo na 'cultura' desta pessoa não pavimenta o caminho para mais tolerância, mais respeito e para um 'ecumenismo global'” (2002: 135-136).

Isso não significa que devamos descartar qualquer projeto de ação afirmativa, como têm argumentado vários autores preocupados com a essencialização das diferenças

31. Infelizmente, não há espaço para aprofundar os debates sobre cultura e etnicidade, as reflexões e inovações teóricas (inclusive, reivindicações de abandonar o conceito de cultura) que surgiram na Antropologia e em disciplinas afins, desde os trabalhos clássicos de C. Geertz. 
que políticas identitárias possam promover. Mas parece-me que está na hora de despedirmo-nos de concepções analíticas e de linguagens que evocam tais "essencializações", inclusive porque estas freqüentemente trazem consigo o perigo de fomentar contra-reações maniqueístas que acirram ainda mais atitudes racistas. E mais: é preciso investir na reflexão teórica, buscando modos mais adequados para pensarmos as diferenças humanas e maneiras politicamente mais acertadas para enfrentarmos as diferentes formas de discriminação. Se os estudos culturais e pós-coloniais e as reflexões sobre transculturalidade e transdiferença não conseguiram certamente resolver a maioria dos problemas, podemos contudo admitir que têm apontado para questões pertinentes.

Para reivindicarmos políticas de combate à discriminação racial, não é necessário, como alegam alguns, recorrermos a "categorias fechadas" de raça/cor. É preciso compro50 var e denunciar o racismo existente. Em vez de desclassificarmos vozes que alertam para o perigo da essencialização das identidades raciais/de cor (tachando-as de reacionárias, anti-negras etc.), parece-me intelectualmente e moralmente mais sincero - e, pensando no sucesso do projeto, mais promissor - optarmos por um outro caminho: o de não esconder perigos e incertezas que projetos políticos, tais como as cotas, podem ocasionar, mas encará-los e problematizá-los abertamente como algo que faz parte de um experimento democrático legítimo. Ninguém pode prever os desdobramentos que a implementação de programas de ação afirmativa acarretará (p. ex., se irá se fortalecer uma tendência de sensibilização e de conscientização da população brasileira para com a problemática da discriminação e/ou se ocorrerá uma "contra-reação" que poderá impulsionar um acirramento de atos discriminatórios).

Penso que, ao transformar o racismo em objeto de comentários cotidianos, o debate sobre as ações afirmativas 
já tem tido um mérito simbólico importante: o de explicitar que há um "problema racial sério" a ser enfrentado. Constato, porém, com certo lamento, que a discussão tem levado, no mundo acadêmico, na grande mídia e pelas ruas do país, a um endurecimento de duas posições: defesa de um "etos" (e/ou de "mitos sociais") versus defesa de um grupo específico. Este enrijecimento (recrudescimento na discussão) pouco tem contribuído para aprofundar a compreensão dos mecanismos e das causas dos processos discriminatórios no Brasil. Estaria na hora de redirecionarmos nosso olhar, aproveitando o que há de frutífero nas tradições antropológicas e sociológicas para avançarmos na análise e, desta forma, abrirmos novos horizontes e, quem sabe, perspectivas mais eficazes de combater o racismo.

\section{Andreas Hofbauer}

é professor do Departamento de Sociologia e Antropologia da Unesp, Campus Marília.

\section{Bibliografia}

A FAVELA, 4 set. 2001.

APPIAH, K. Anthony. 1997. "The multiculturalist misunderstanding”. The New York Review of Books, 44, vol. 15.

BARTH, Fredrik (org.). 1969. Ethnic groups and boundaries. Bergen: Universitets Forlaget.

BASTIDE, Roger; FERNANDES, Florestan. 1951. O preconceito racial em São Paulo. São Paulo: Publicações do Instituto de Administração.

lo: Companhia Editora Nacional.

1971. Brancos e negros em São Paulo. São Pau-

BAUMANN, Gerd. 1999. The multicultural riddle: Rethinking national, ethnic and religious identities. New York: Routledge.

BAY, Mia. 2000. The white image in the black mind. New York: Oxford University Press.

BEER, Bettina. 2002. Körperkonzepte, interethnische Beziehungen, Rassismustheo- 
rien. Berlin: Dietrich Reimer.

BENEDICT, Ruth. 1987. Raza: ciencia y política. Mexico: Fondo de Cultura Económica.

BOURDIEU, Pierre; WACQUANT, Loic. 1998. "Sur les ruses de la raison impérialiste”. Actes de la Recherches en Sciences Sociales, n. 121-122.

CARTER, Bob. 2000. Realism and racism. Concepts of race in sociological research. London: Routledge.

CAVALLI-SFORZA, Luca e Francesco. 1993. Chi siamo. La storia della diversità umana. Milão: Mondadori.

COX, Oliver Cromwell. Caste, class E race. New York: Monthly Review Press.

DA MATTA, Roberto. 1997. "Notas sobre o racismo à brasileira". In: SOUZA, Jessé (org.). Multiculturalismo e racismo. Brasília: Paralelo 15.

DUNN, Leslie C. e DOBZHANSKY, Théodosius. 1946. Heredity, Race, and Society. New York: Penguin.

ERIKSEN, Thomas Hylland. 1993. Ethnicity and Nationalism - Anthropological Perspectives. London: Pluto Press.

. 2002. "Between universalism and relativism: a critique of the UNESCO concept of culture”. In: COWAN, Jane K. DEMBOUR, MarieBénédicte e WILSON, Richard A. Culture and Rights. Cambridge: Cambridge 52 University Press.

ERIKSEN, Thomas Hylland. 2004. What's Anthropology? London: Pluto Press.

FERNANDES, Florestan. 1978. A integração do negro na sociedade de classes. São Paulo: Ática. vol. I e II.

FOLHA DE S. PAULO, 6 maio. 1979; 5 dez. 1979.

FOLHA DIRIGIDA, 17 set. 2002.

FREDRICKSON, George M. 2001. "Race and racism in historical perspective: comparing the United States, South África, and Brazil”. In: HAMILTON, Charles V. et alii. Beyond racism. London: Boulder. . 2002. Racism, a Short History. Princeton: Princeton University Press.

FREYRE, Gilberto. 1951. Sobrados e mocambos. Rio de Janeiro: José Olympio. . 1992. Casa grande Ẽ senzala. Rio de Janeiro: Record.

FRY, Peter. 1995-1996. "O que a Cinderela negra tem a dizer sobre a 'política racial' no Brasil”. Revista USP, 28.

. 2000. "Politics, nationality, and the meaning of 'race' in Brazil". Daedalus, Journal of the American Academy of Arts and Sciences, vol. 129, n. 2. . 2003. "Introduzindo o racismo". O Globo, 21 de março. 
GÓES, José Roberto Pinto de. 2001. "Cotas raciais e políticas afirmativas: a peleja entre o padre Antônio Vieira e dois engraxates cariocas". O Globo, 14 de dezembro.

2004. "Cotas, um remédio que é veneno". O Estado de São Paulo, 13 de abril.

GUIMARÃES, Antonio Sérgio. 1995. "Racismo a anti-racismo no Brasil". Novos Estudos, n. 43.

. 1997. "A desigualdade que anula a desigualdade. Notas sobre a ação afirmativa no Brasil”. In: SOUZA, Jessé, Multiculturalismo e racismo. Brasília: Paralelo 15. .1999. Racismo e anti-racismo no Brasil. São Paulo: Edições 34. 2002. Classes, raças e democracia. São Paulo: Editora 34. . 2003. "A modernidade negra”. Teoria e pesquisa, São Carlos-SP: UFSCar, n. 42-43. . 2005 "Intelectuais negros e a modernidade no Brasil" Disponível em: <www.fflch.usp. br/sociologia/asag/Intelectuais\%20negros $\%$ 20modernidade\%20no\%20Brasil. pdf $>$. Acesso em: 23.5.2005.

HALL, Stuart. 2003. Da diáspora. Identidades e mediações culturais. Belo Horizonte: Ed. UFMG.

HASENBALG, Carlos A. 1979. Discriminações e desigualdades raciais no Brasil. Rio de Janeiro: Graal.

HOFBAUER, Andréas. 1999. Uma história de branqueamento ou o negro em questão. Dissertação. São Paulo: USP.

HOFBAUER, Andréas. 2003. "O conceito de 'raça' e o ideário do 'branqueamento' no século XIX - Bases ideológicas do racismo brasileiro”. Teoria e pesquisa, São Carlos-SP: UFSCar, n. 42-43.

HUND, Wulf D. 1999. Rassismus. Die soziale Konstruktion natürlicher Ungleichheit. Münster: Westfälisches Dampfboot.

. 2003. "Inclusion and exclusion: dimensions of racism".

Wiener Zeitschrift zur Geschichte der Neuzeit, vol. 1.

IANNI, Octavio. 1988. As metamorfoses do escravo. São Paulo: Hucitec.

JACOBSON, Matthew Frye. 1998. Whiteness of a different color. London: Havard University Press.

JACQUARD, Albert. 1978. Éloge de la différence: la génetique et les hommes. Paris: Seuil.

JORNAL DA GLOBO NEWS, 26 mar. 2004.

LÉVI-STRAUSS, Claude. L'identité. Paris: Puf.

LEWONTIN, Richard C. 1972. "The Apportionment of Human Diversity". Evolutionary Biology, n. 6.

LÓPEZ, Ian F. Haney. 1996. White by law. The legal construction of race. New 
York: New York University Press.

MAGGIE, Yvonne. 1996. “Aqueles a quem foi negada a cor do dia': as categorias cor e raça na cultura brasileira”. In: MAIO, Marcos Chor, SANTOS, Ricardo Ventura (orgs.). Raça, ciência e sociedade. Rio de Janeiro: Fiocruz: CCBB.

; FRY, Peter. 2002. "O debate que não houve: a reserva de vagas para negros nas universidades brasileiras". ENFOQUES - Revista eletrônica. Rio de Janeiro.

MALIK, Kenan. 1996. The meaning of race. Houndsmills: MacMillan Press.

MARSHALL, Eliot. 1998. "DNA studies challenge the meaning of race". Science, vol. 282.

MELISH, Joanne Pope. 1998. Disowning slavery. Ithaca: Cornell University Press.

MILES, Robert. 1992. Rassismus: eine Einführung in die Geschichte und Theorie eines Begriffs. Hamburg: Argument. . 1993. Racism after "race relations". London: Routledge. ; BROWN, Malcolm. 2004. Racism. London: Routledge. ; TORRES, Rodolfo D. 1999. "Does race matter? Transatlantic perspectives on racism after 'race relations'”. In: TORRES, Rodolfo D. et alii. Race, identity and citizenship. Malden: Blackwell.

MILLS, Gary B. 1981. "Miscegenation and the free negro in Antebellum 'Anglo' Alabama: a reexamination of Southern race relations”. The Journal of American History, vol. 68, n. 1.

MONTAGU, Ashley. 1997. Man's most dangerous myth: the fallacy of race. London: Altamira Press.

MOURA, Clóvis. 1983. Brasil: as raízes do protesto negro. São Paulo: Global. . 1994. Dialética radical do Brasil negro. São Paulo: Anita.

0 GLOBO, 14 abr. 2004.

PARK, Robert Ezra. 1950. Race and culture. Glencoe: The Free Press.

PATTERSON, Thomas C. 2001. A social history of Anthropology in the United States. Oxford: Berg.

PENA, Sérgio D. J. 2000. "Retrato molecular do Brasil". Ciência hoje, vol. 27, n. 159 .

; BORTOLINI, Maria Catira. 2004. "Pode a genética definir quem deve se beneficiar das cotas universitárias e demais ações afirmativas?”. Revista Estudos Avançados, São Paulo: USP, vol. 18, n. 50. (Dossiê: O negro no Brasil)

PIETERSE, Jan Nederveen. 1992. White on black. New Haven: Yale University Press.

PINTO, Regina Pahim. 1993. O movimento negro em São Paulo: luta e identida- 
de. Dissertação. São Paulo: USP.

RECKWITZ, Andreas. 2000. Die Transformation der Kulturtheorien. Göttingen: Velbrück.

. 2001. "Multikulturalismustheorien und der Kulturbegriff: Vom Homogenitätsmodell zum Modell kultureller Interferenzen”. Berliner Jounal für Soziologie, (11), vol. 2.

SANSONE, Livio. 1996. "Nem somente preto ou negro. O sistema de classificação racial no Brasil que muda”. Afro-Ásia, n. 18.

SANTOS, Ricardo Ventura e MAI0, Marcos Chor. 2004. "Qual 'retrato do Brasil'? Raça, biologia, identidades e política na era da genômica”. Mana 10 (1).

SCHWARCZ, Lilia Moritz. 1995. "Complexo de Zé Carioca. Notas sobre uma identidade mestiça e malandra”. Revista Brasileira de Ciências Sociais, n. 29. . 1996. "Questão racial no Brasil”. In: SCHWARCZ, Lilia Moritz, REIS, Letícia Vidor de Sousa (orgs.). Negras imagens. São Paulo: Estação Ciência-Edusp.

1998. "Nem preto nem branco, muito pelo contrário: cor e raça na intimidade". In: SCHWARCZ, L. M. (org.). História da vida privada no Brasil. São Paulo: Companhia das Letras.

.1999. "Questão racial e etnicidade”. In: MICELI, Sergio (org.). O que ler na ciência social brasileira (1970-1995) (Antropologia). São Paulo: Anpocs. vol. II. . 2001. Racismo no Brasil. São Paulo: Publifolha.

SOLOMOS, John; BACK, Les. 1996. Racism and society. Houndmills: MacMillan.

TAGUIEFF, Pierre-André. 1998. "Die Metamorphosen des Rassismus und die Krise des Antirassismus”. In: BIELEFELD, Ulrich (org.). Das Eigene und das Fremde. Hamburg: Hamburger Edition HIS.

TELLES, Edward. 2003. Racismo à brasileira. Rio de Janeiro: Relume Dumará. TEMPLETON, Alan R. 1999. "Human races: a genetic and evolutionary perspective". American Anthropologist, vol. 100, n. 3.

TURRA, Cleusa e VENTURI, Gustavo (orgs.). 1995. Racismo cordial. São Paulo: Ática.

UNESCO, TRC. 1952. The race concept. Paris: Imprimerie des Arts et Manufactures/UNESCO.

VERMEULEN, Hans e SLIJPER, Boris. 2000. "Multiculturalism and culturalism. A social scientific critique of the political philosophy of multiculturalism". Paper presented at the Second EuroConference Democracy beyond the nation-state. Perspectives on a post-national order. Atenas, 5 a 7 de outubro.

WADE, Peter. 1993. “'Race', nature and culture”. Man, n. 28, pp. 17-34. 
WELZ, Gisela. 1994. "Die soziale Organisation kultureller Differenz: zur Kritik des Ethnosbegriffs in der anglo-amerikanischen Kulturanthropologie". In: BERDING, H. (org.). Nationales Bewußtsein und kollektive Identität. Frankfurt: Suhrkamp.

ZERGER, Johannes. Was ist Rassismus? Göttingen: Lamuv. 


\section{AÇÕES AFIRMATIVAS E O DEBATE SOBRE RACISMO NO BRASIL}

ANDREAS HOFBAUER

O tema "ações afirmativas" tem dividido a opinião pública e esquentado o debate acadêmico. Enquanto alguns especialistas e militantes negros entendem a introdução de ações afirmativas como uma forma de combate ao racismo, uma vez que, segundo esta interpretação, a discriminação positiva ajudará os historicamente desprivilegiados a criar e fortalecer uma identidade positiva, outros vêem em tais medidas um ataque perigoso contra a "maneira tradicional brasileira" de se relacionar com as "diferenças humanas" e temem que políticas como essas possam instigar conflitos raciais abertos. Embora os defensores e opositores à introdução de projetos de ação afirmativa raramente explicitem o que entendem por racismo e como interpretam este fenômeno social, é possível detectar nesses discursos distintas linhas de argumentação que remetem a orientações teóricas diferentes no que diz respeito à análise de categorias como "raça" e "cor".

Palavras-chave: Ações Afirmativas; Racismo; Teoria Social; Brasil.

\section{AFIRMATIVE ACTIONS AND THE DEBATE ON RACISMI IN BRAZIL}

The "affirmative action" issue has split the public opinion and heated up the academic debate. While some experts and black activists see the affirmatives actions as a way to fight racism, since the positive discrimination could help the historically underprivileged to create and empower a positive identity, others see such measures as a dangerous attack against the "traditional brazilian way" of dealing with "human differences". The latter fear that such policies may unleash racial conflicts. Although both sides barely explain what they mean for racism and how they understand that social phenomenon, it is possible to discern in those discourses different lines of argument, 
which can be related to different theoretical orientations about the analysis of such concepts as "race" and "color".

Keywords: Afirmative Actions; Racism; Social Theory; Brazil. 